Received: 30/06/2018

Revision: 15/11/2018

Accepted: $19 / 11 / 2018$

OnlineFirst: 16/12/2018

\title{
Cooperative Learning Strategies to Enhance Writing Skills among Second Language Learners
}

\section{Qismullah Yusuf}

Dr., (1) Faculty of Teacher Training and Education, Syiah Kuala University, Indonesia, (2) Universiti Pendidikan Sultan Idris, Malaysia, yusufqismullah@gmail.com

\section{Zalina Jusoh}

M.Ed., (1) Sekolah Menengah Kebangsaan Sinar Bintang, Kuala Lumpur, Malaysia, (2) Universiti Pendidikan Sultan Idris, Malaysia,_zalina_76@msn.com

\section{Yunisrina Qismullah Yusuf}

Dr., corresponding author, Faculty of Teacher Training and Education, Syiah Kuala University, Indonesia, yunisrina.q.yusuf@unsyiah.ac.id

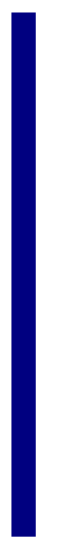

The mastery of the writing skills is crucial, not only among the school children, but also to everyone. The use of Cooperative Learning (hereafter, CL) has become increasingly popular in recent years as pedagogy trends worldwide. It has shifted from teacher-centred to learner-centred methods. Among the methods endorsed in teaching writing is the application of CL. This research investigated the effects of CL to improve the writing skill of ninth grade students in a middle school in Kuala Lumpur. This research used the quasi experimental design, with pre-test and posttest of the narrative essays as the instruments. The data were further analysed by employing descriptive and inferential statistics. The students' writing were scored on the five writing components, they are vocabulary, organization, grammatical accuracy and mechanics. The results showed that the students had increased in their writing scores from the pre-test to the post test after the application of CL in the class. Subsequently, the results indicate positive effects of CL in improving the writing skill of students at the school, and they are also discussed in the paper.

Keywords: writing, cooperative learning, quantitative research, second language learners, teaching, learning

\section{INTRODUCTION}

The Ministry of Education in Malaysia has English to be taught in all primary and secondary schools as a second language. The specified four skills to be mastered by the students and taught integratedly by teachers are listening, speaking, reading and writing.

Citation: Yusuf, Q., Jusoh, Z., \& Yusuf, Y. Q. (2019). Cooperative Learning Strategies to Enhance Writing Skills among Second Language Learners. International Journal of Instruction, 12(1), 13991412. https://doi.org/10.29333/iji.2019.12189a 
These are prescribed in the curriculum specifications (Pusat Perkembangan Kurikulum [Curriculum Development Centre], 2003). Nevertheless, writing is well known to be the daunting skill to be mastered by language learners among the others. Based on the prescribed syllabus as suggested by the Ministry of Education, students must learn different genres of writing, which include expository, descriptive, reflective, narrative and argumentative.

Many researchers believed that one's abilities in language are made perfect in writing. According to Boals (2012), writing is a process of meaning making and a series of related text-making activities: generating, arranging and developing ideas in sentences: drafting, shaping, rereading the text, editing and revising (Gould, DiYanni \& Smith, 1990). Writing is also known as a creative process because it is the process of reaching out for one's thought and discovering them. A good piece of writing demands standard forms of grammar, syntax and word choice, not forgetting good mechanics, organization of paragraph, content. The writer's process and purpose should be clear, fluent and effective communication of ideas (Raimes, 1983).

When learning a second language, writing is one aspect of language that has always posed problems among the other language skills (i.e. reading, speaking and listening). It is not only to the learners who are learning it, but also to the teachers who are teaching it (Kustati \& Yuhardi, 2014). Students have problems in fulfilling the requirements of writing due to low proficiency of the language. At the same time, students' lack knowledge of English vocabulary, grammar, spelling, and punctuation further contribute to the students' lack of interest in writing (Karim, 2012). English teachers at the same time are often confronted with the dilemma of choosing suitable teaching methods to overcome writing apprehension in their students, especially in Malaysia where English is treated as a second language.

Different methods are employed by English teachers around the world in teaching writing in the classrooms. Among the methods that are deemed to suit the teaching of writing is the corporation of Cooperative Learning or CL (Kagan \& High, 2002). Numerous researchers around the world are studying practical applications of CL principles and methods for helping students work together more effectively (Jacobs, Power \& Inn, 2002). CL has been found to be successful and productive teaching methods to develop learners' linguistic, social and communicative skill because it provide maximum chances for students-students interaction with consequential input and output in a supportive atmosphere (Ahangari \& Samadian, 2014). What we can say is that cooperative group work is not only just putting the students together in groups and asking them to work on the task given, but its principles at the same time help students and teachers understand on what is involved in helping the students to succeed. CL methods embody those principles in an attempt to provide structure for students' interaction (Baloche, 1998; Johnson \& Johnson, 1999).

Since CL is known to provide positive interdependence support on student group members in enhancing their writing skills, therefore the researchers of this study intend to further investigate how CL provides knowledge that is responsible for developing writing skill by answering the following research question: Does group work in CL 
improve the students' writing skill in essays? In view of that, the results of this study are expected to provide benefits and information to other parties such as teachers, school administrators, the Ministry of Education and Curriculum Development centers. Among them are as a source of knowledge to the teacher trainees at universities and institutes of teacher education as one of the alternative methods in the teaching and learning processes.

\section{LITERATURE REVIEW}

\section{Cooperative Learning}

Cooperative Learning or CL is an instructional strategy based on the human instinct of cooperation. CL is described as a method where students work in small groups and are given rewards and recognition based on their groups' performance (Slavin, 1980). Mandal (2009) adds that the idea behind the CL methods are that when group rather than individuals are rewarded, students will be motivated to help one another to master academic materials. In cooperative group work, each member of a team is responsible not only for learning what is taught, but also to help other members of the group to learn and create atmosphere of achievement. It can be said that students learn effectively when they work cooperatively. This statement is strengthened by Slavin (1980) who say learners will benefit more from sharing each other's thoughts when working together as a group rather than working alone. Richards and Renandya (2002) at the same time agree that $\mathrm{CL}$ is a tool of some methods which teachers use to encourage mutual helpfulness in the groups and the active participation of all members.

In order to construct a lesson in the CL method, Johnson and Johnson (2000) outline five fundamental elements of CL as described below:

1. Positive Interdependence: to achieve the targeted goal, student team members depend and rely on one another. Every student team member has to contribute ideas and views, and further share responsibility of performing good work in completing the team tasks assigned to them.

2. Individual and Group Accountability: Every student team member must be responsible for contributing their own share of the work and master all materials to be learnt for the group's success. The performance of each individual must be assessed and the result is given back to the group.

3. Face to Face Promotive Interaction: another feature of CL is that it emphasizes on small group interaction. Even though some tasks are completed individually, group members at the same time play an important role by providing one another with feedback, challenging reasoning and conclusions, supporting and encouraging one another to achieve the group's goals.

4. Interpersonal and Small Group Skills: these are the basic skills in teamwork. Group members must learn interpersonal skill such as active learning, staying on task, asking questions, encouraging, helping others in order to facilitate teamwork, create trust and enhance communication. 
5. Group Processing: group processing is reflecting on a group session to describe what member actions were helpful and unhelpful and make decisions about what actions to continue or change. It also helps to promote self-esteem and positive attitudes towards the learning process.

To conclude, CL is a group-learning activity to achieve a common goal (Artz \& Newman, 1990). Its establishment for learning is based on the socially structured exchange of information between student team members, where each member is responsible for his or her own learning and should be able to motivate each other (Richards \& Rodgers, 2001).

\section{Teaching Writing in the ESL Context}

Brown (2007) proposes that writing is a thinking process that can be planned and given with an unlimited number of revisions before its release. In addition, Harmer (2004) states that writing encourages students to focus on accurate language use. It is because students consider how a language is used when the students engage in their writing process. This activity will provoke language development because the students resolve problems what writing puts in their minds.

Troyka (2010) adds that the purposes of writing are so that writers can express themselves, provide information, persuade readers and create literary work. These purposes contribute importantly to human thought and culture. Through writing, message to others on particular topic or subject are delivered. Brereton (1995) strengthens the opinions from Troyka (2010) by saying that, in the context of writing, there are three important elements, namely the text or the message (the subject to be discussed), the writer who is presenting it and the reader (the audience to be addressed). However, teaching writing is not as easily said than done because to produce students with impressive writing skill seems to be an overwhelming task for teachers. Consequently, writing skill is considered as a complex cognitive skill because it requires the students to employ proper intellectual skills, cognitive strategies, verbal information, language rules and apposite motivation (Tierney, et al., 1989). In order to ensure the students excel in writing, teachers have to adapt various methods in teaching writing. One of the methods that is widely used today is CL. Kagan and High (2002) show their support in this matter by saying that the application of CL has shown constructive outcomes in improving students' writing skill.

In Malaysia, English is taught as a second language (ESL), which means that the teaching of English is not as easy as expected. Students are anticipated to master all the four language skills, namely reading, speaking, listening and writing. Among all the four skills, writing is said to be the most difficult skill to learn and also to teach. To produce a piece of writing as written communication requires the writer's ability to use not only his or her linguistics competence but also his or her communicative competence (Mukminatin, 1997). It means the students need to compose a text using certain language rules and conventions, and concept the knowledge they have collected on paper (Byrne, 1993). 
Writing is not only about linguistic skills, it also involves general problem-solving mental activities (cognitive). The problems that we encounter and the way we solve them more or less different because of the idiosyncratic features of our individual cognitive systems (Byrne, 1993). In writing, writers need to handle several separate sub process simultaneously, such as developing content, coherence, readership awareness and linguistic choices. Starkey (2004) informs that writing in English within an academic context requires some criteria of acceptability relative to different aspects of writing that include organization, vocabulary, language use, punctuation, accurate capitalization and paragraphing. He added that effective piece of writing is the one that is organized, clear and coherent with accurate language and effective word choice.

\section{METHOD}

\section{Design}

This study investigated the effects of using CL in improving writing skills among the ninth grade students in a high school in Kuala Lumpur. The study adopted the quantitative research method. The quasi-experimental research design was employed since it involved on-going measurement and the group experienced treatment within a period of time. According to White and Sabarwal (2014, p. 1), quasi-experimental research designs "test causal hypotheses to identify a comparison group that is as similar as possible to the treatment group in terms of baseline (pre-intervention) characteristics".

\section{Sample}

Data were collected from one class that comprise 30 students (i.e. 15 males and 15 females). These students are of mix ability of intermediate and low proficiency levels in English language. These levels were based on their first monthly test at the beginning of the school year. The test results revealed that no student obtained grade A, but five students obtained grade B, three students obtained grade $\mathrm{C}$, seventeen students obtained grade D. Meanwhile, the other five students obtained grade E. These students were never taught using CL before by their teachers.

\section{Instruments}

The research instruments used in this study were the pre-test and post-test writing on narrative essays. These tests were conducted to measure the students' writing skill based on the ninth grade syllabus that has been arranged by the Malaysian Ministry of Education. The structure of the writing tests were adapted from the Pentaksiran Pelajar Tingkatan Tiga (PT3) [Form Three (Ninth Grade) Student Assessment] of English, or the lower secondary national examination of English. Therefore, the students were familiar of these tests because they had gone through the test forms before since they were in the seventh grade.

Moreover, the test questions corresponded to the ninth grade syllabus as approved by the Malaysian Ministry of Education. They were based on the topics that the students had to study in the ninth grade. Thus, the topic evaluated in the tests was "School Life", where the students were required to write a narrative genre. 


\section{Procedures}

This research was conducted in the first semester of the class. It included the pre-test, treatment session and the post-test until the end of actions. In conducting the research, the second author was the teacher who followed closely the English syllabus and lessons in the class, which was held two times a week, every Monday, and Thursday. The duration was 70 minutes ( $2 \times 35$ minutes) for one meeting.

The research was conducted in a twelve-week time. The first week was used to give out the pre-test writing on the narrative essay of "School Life". The following three weeks were used to enlighten the students on CL approaches. They were the Jigsaw (Aronson \& Patnoe, 2011) and the Students Team Achievement Division (STAD) (Slavin, 2011). The next six weeks were used to execute the CL lesson plans. The eleventh week was to administer the post-test. Finally, the last week was to evaluate the tasks required. The procedure is further described in the following sub-sections.

\section{Essay Writing (Pre-test and Post-test)}

In the first week of research, the students were given the pre-test of essay writing on the narrative genre about "School Life". The students were to write an essay for 40 minutes and in not less than 120 words based on pictorial stimulus. Afterwards, after completing six weeks of CL lessons, they were given their post-test with the same topic as well. The post test was conducted on the eleventh week, hence it was expected that they did not evoke on the pre-test given at the beginning of the year. At the end, analytical scoring was conducted to evaluate the students' pre-test and post-test. In this scoring, each writing component is assessed separately and the total score is based on the totality of the components (Ismail \& Maasum, 2009).

\section{Cooperative Learning Treatment}

The CL treatment in the writing class started from the fifth until the tenth week, where twenty-four periods (thirty-five minutes per period) were maneuvered for the CL treatment. During the treatment, the students were exposed to two types of CL methods, which were Jigsaw and Student Teams-Achievement Division (STAD). These two methods were very flexible and could be implemented in almost all subjects. Based on the pre-test scores and their level of proficiency, few small groups were created according to the principles of CL. There were six equal teams out of the thirty students, consisting of male and female students. Each group comprised one weak, three average and one high performance students.

At first, the teacher assigned each student of a team to gather information on a topic. After that, these students discussed the topic with other students from other teams who also acquired similar information on the topic given as a part of the Jigsaw method. This team is called the 'expert group'. Then, once they finished their discussion, they went back to their teams (home group) and shared the information they have gained from the discussion with their team members. During this process, the students were to exchange ideas, brainstorm and discuss on the given topic based on the information they collected from the expert teams. Team members cooperated together on the task given by the 
teacher to extend and help boost the material taught. The main function of the team was to ensure that all of their members could surmount the material and essentially ready to do the quiz (Slavin, 1995).

The next phase was to familiarize students with their roles in the team along with the teacher's roles and expectations. This employed the STAD method. Each member in a team was assigned to a role and each session the roles changed so that each member played all the roles during the treatment session. It was hoped that giving the team members these roles and responsibilities would result in high quality learning and promoted positive interdependence and individual accountability among the learners (Johnson \& Johnson, 1994). Then the teacher asked one member of each team to become the presenter and present the team's work. She gave immediate feedbacks after the presentation and announced the team with the best presentation as a winner. Slavin (1995) outlines four key components in the implementation of STAD in the classroom. They are class presentations, teams, quizzes, and team recognition (see Yusuf, Natsir \& Hanum, 2015).

\section{Analysis}

In technique of data analysis, the pre-test and the post-test were to verify whether there was a significant difference in the students' writing skill. The components being scored were content, vocabulary, organization, grammar and mechanics, before and after the application of CL in the writing class. The dependent variable is the students' writing skill in the tests, and the independent variable is the CL method application in the writing class. The data from these tests were analysed using descriptive and inferential statistics. The statistical software, SPSS version 23, was utilized for the inferential statistics. Meanwhile, descriptive statistics was to analyse the pre-test and post-test by calculating the mean, standard deviation and percentage of each component. Next, inferential statistics that adopts paired sample t-test analysed the difference in the mean scores of the writing skills in both pre-test and post-test. The paired-samples t-test was applied since there was one group of students in this study, and the data from them were collected at two different times (Pallant, 2001).

\section{FINDINGS}

\section{Pre-test and Post-test}

The post-test score results showed better achievement from the students compared to the pre-test score results in writing of the narrative genre. Table 1 and Table 2 show the difference of main scores in the five writing components of content, vocabulary, organization, grammar and mechanics in the pre-test (refer to Table 1) and post- test (refer to Table 2) of the narrative essays. 
Table 1

Pre-test

\begin{tabular}{llllllll}
\hline & $\mathrm{N}$ & Range & Minimum & Maximum & Mean & Std. Deviation & Variance \\
\hline Before CL & 30 & 44 & 40 & 84 & 57.57 & 9.971 & 99.426 \\
\hline Content & 30 & 24 & 12 & 36 & 26.30 & 5.578 & 31.114 \\
\hline Vocabulary & 30 & 5 & 4 & 9 & 6.70 & 1.055 & 1.114 \\
\hline Organization & 30 & 11 & 6 & 17 & 10.47 & 2.921 & 8.533 \\
\hline Grammar & 30 & 4 & 3 & 7 & 5.17 & 1.117 & 1.247 \\
\hline Mechanic & 30 & 13 & 3 & 16 & 8.93 & 3.016 & 9.099 \\
\hline Valid N (Listwise) & 30 & & & & & & \\
\hline
\end{tabular}

Table 2

Post-test

\begin{tabular}{llllllll}
\hline & $\mathrm{N}$ & Range & Minimum & Maximum & Mean & Std. Deviation & Variance \\
\hline After CL & 30 & 41 & 53 & 94 & 64.50 & 9.811 & 96.259 \\
\hline Content & 30 & 21 & 17 & 38 & 29.53 & 4.995 & 24.947 \\
\hline Vocabulary & 30 & 4 & 6 & 10 & 7.60 & .968 & .938 \\
\hline Organization & 30 & 12 & 7 & 19 & 11.20 & 3.123 & 9.752 \\
\hline Grammar & 30 & 4 & 5 & 9 & 6.83 & 1.053 & 1.109 \\
\hline Mechanic & 30 & 14 & 4 & 18 & 9.43 & 3.256 & 10.599 \\
\hline Valid N (Listwise) & 30 & & & & & & \\
\hline
\end{tabular}

The scores shown in Table 1 and Table 2 show that in the pre-test, the marks ranged from 40 to 84 , meanwhile in the post test, the marks ranged from 53 to 94 . This shows a notable transformation from the results of these two tests. There is a 13 mark increase in minimum score between them, and a 10 mark increase in the maximum score. Therefore, the students had done better in the post-test compared to the pre-test. The CL methods had helped them improve their writing skills in narrative essays based on the increase of the scores. Furthermore, the mean score for the post-test is also found to be higher compared to the pre-test. In the post-test the mean score was 64.50 , while for the pre-test the mean score was 57.57. It clearly demonstrates that there was a 6.93 increase in the mean score of the post-test. This indicates that the students' writing skill improved after the teacher employed CL in teaching writing.

\section{Narratives Pre-test and Post-test Scores}

To decide whether there was a statistical difference between the pre-test and the posttest results, paired-samples t-test was conducted. Based on the calculations, the numbers do show significant differences, and these are displayed in Table 3 and Table 4, where $t(29)=-14.323, p=0.00$. This shows that the $p$ value of $(0.00)$, is less than 0.05 , therefore it demonstrates that there is a significant difference for the composite scores in students' writing skill in the post-test compared to the pre-test. The mean for the post test is 64.50 , $\mathrm{SD}=9.811$, and the mean for the pre-test is $57.57, \mathrm{SD}=9.971$. 
Table 3

Paired samples statistics for narrative pre-test and post-test composite scores

\begin{tabular}{llllll}
\hline & & Mean & N & Std. Deviation & Std. Error Mean \\
\hline Pair 1 & Pretest before CL & 57.57 & 30 & 9.971 & 1.820 \\
\cline { 2 - 6 } & Posttest after CL & 64.50 & 30 & 9.811 & 1.791 \\
\hline
\end{tabular}

Table 4

Paired sample t-test for narrative pre-test and post-test composite scores

\begin{tabular}{|c|c|c|c|c|c|c|c|c|}
\hline & \multicolumn{5}{|c|}{ Paired Differences } & \multirow{4}{*}{\multicolumn{2}{|c|}{ df }} & \multirow{4}{*}{ If $\begin{array}{l}\text { Sig. (2- } \\
\text { tailed) }\end{array}$} \\
\hline & \multirow[t]{3}{*}{ Mean } & \multirow{3}{*}{$\begin{array}{l}\text { Std. } \\
\text { Deviation }\end{array}$} & \multirow{3}{*}{$\begin{array}{l}\text { Std. Error } \\
\text { Mean }\end{array}$} & \multirow{2}{*}{\multicolumn{2}{|c|}{$\begin{array}{l}\text { 95\% Confidence } \\
\text { Interval of the } \\
\text { Difference }\end{array}$}} & & & \\
\hline & & & & & & & & \\
\hline & & & & Lower & Upper & & & \\
\hline $\begin{array}{l}\text { Pair 1 Pretest before } \\
\text { CL }- \\
\text { Posttest after } \\
\text { CL }\end{array}$ & -6.933 & 2.651 & .484 & -7.923 & -5.943 & -14.323 & 29 & .000 \\
\hline
\end{tabular}

The increased mean scores from the pre-test to the post-test numbers in Tables 3 and 4 signify that the students had performed better in writing after the CL methods were implemented in the teaching and learning process. Table 5 further reveals the paired samples statistics for the pre-test and post-test in the components of writing being evaluated and scored.

Table 5

Paired samples statistics for narrative pre-test and post-test of the five components of writing

\begin{tabular}{llllll}
\hline Pair & Component & Mean & $\mathrm{N}$ & Std. Deviation & Std. Error Mean \\
\hline \multirow{1}{*}{1} & Content pre-test & 26.30 & 30 & 5.578 & 1.018 \\
& Content post-test & 29.53 & 30 & 4.995 & .912 \\
\cline { 2 - 6 } & Vocabulary pre-test & 6.70 & 30 & 1.055 & .193 \\
& Vocabulary post-test & 7.60 & 30 & .968 & .177 \\
\cline { 2 - 6 } & Organization pre-test & 10.47 & 30 & 2.921 & .533 \\
& Organization post-test & 11.20 & 30 & 3.123 & .570 \\
\cline { 2 - 6 } & Grammar pre-test & 5.17 & 30 & 1.117 & .204 \\
& Grammar post-test & 6.83 & 30 & 1.053 & .192 \\
\cline { 2 - 6 } & Mechanic pre-test & 8.93 & 30 & 3.016 & .551 \\
& Mechanic post-test & 9.43 & 30 & 3.256 & .594 \\
\hline
\end{tabular}

The results in Table 5 illustrates that the scores of each component of writing increased from the pre-test to the post-test. This once again proved that CL treatment helped the students in improving their writing components to produce a better essay.

\section{DISCUSSION}

In the process of teaching writing, the teacher used two CL methods which were Jigsaw and STAD (Student Team Achievement Division) to see which of the method gave better results in enhancing students' writing ability. Surprisingly, both methods gave almost the same effect on the students' motivation and perception towards writing. At 
the beginning of the year, they showed negative perception towards writing. They were unhappy, unmotivated and spent too much time before they could start doing the exercises on writing. However, the incorporation of $\mathrm{CL}$ in the writing class had proven to give positive effect on the students' performance. Artz and Newman (1990) explain that this method organizes a classroom in such a way that students are able to work together in cooperative teams, each with a role that can ensure interdependence. Since the learning environment is less threatening, it increases their participation in tasks given by the teacher and reduces their anemic competition. Furthermore, as it creates studentcentered environment therefore it reduces the teacher's dominance in the classroom.

After six weeks of CL treatment, the students scored better in the writing of narrative essays (i.e. as evidenced in the post-test results). Most of them showed better understanding on the five writing components of content, organization, vocabulary, grammar and mechanics through cooperative writing. During the CL treatment, they started to pay attention and showed better responses towards the writing lessons. This could be due to the new methods applied in the class. The idea of putting them in small groups had given them more confidence in sharing ideas with their peers of different backgrounds. Working together as a team develops their interaction and communication skills such as active listening, speaking and turn taking. Cooperative group work could also foster cognitive skills such as problem-solving, discovery learning and creativity.

In Jigsaw, the students with the same topics met members of the expert groups to discuss them. They took notes and later on, they had to teach their teammates (home group). Before starting their writing task, they would have to meet the expert group and discussed the ideas before they could start moving to their prewriting stage in their own group with the other teammates. Whenever a problem arises, they should try to find their own solution before seeking help from the teacher. Thus, these kind of activities boosted the students' confidence level, especially the low proficiency students, to learn and develop social relationship, learn to value and respect others, learn to cope up with different ideas and how to tolerate with conflict.

STAD also gave good impacts on the students' learning process in this study, especially the 'group recognition' phase. Similar to the findings by Yusuf, Natsir and Hanum (2015), low achieving students in this study could also see their contribution to the group if they showed improvement in the quizzes. The success of STAD lies in the concept that each member has a common goal of doing well and obtaining the group reward. They would then do their best and be eager to help others. Besides that, this method could also increase their self-esteem and motivate them to learn more in the classroom (Slavin, 1995). Slavin (1995) further added that the students in STAD class think that their success does not depend on their luck, but depends on how they work. The students are also intrinsically motivated to do their best.

Nevertheless, to every advantage in teaching methods, some disadvantages were also found during the employment of CL in teaching writing of this experiment. In this study, it was found that some students could not get some group members to cooperate in the group work given - there were three possible reasons that this situation could happen: 
a) Personality conflict; where this type of students did not like sharing and working with other students. They wanted to show that they were the best and deserve to get the teacher's recognition. To solve such problem, the teacher restarted the activity by reminding them that they would benefits from CL. By doing so, it is expected that they understand the expression of "two heads are better than one". She gave them rewards and praises if they are able to successfully work in teams. She also monitored these kinds of groups and willingly offered help if there were any conflicts between the group members.

b) Types of students who did not have the sense of belonging towards the group; these students might not understand the concept of positive interdependence where everyone "sink and swim together" or "one for all, and all for one". Here, each member's success is interdependent on the success of their group mates. The teacher solved this problem by explaining to them the importance of positive interdependence. This means that each student is responsible for learning the assigned material, and they must also make sure that their other team members learn the assigned material, too, to successfully complete the assignment together.

c) Unintended unequal distribution of the group work; it was found that he high proficiency students did most of the group work. Due to their high proficiency level, they were left to do the work without much help from the other weak students. And so, to solve this problem, the teacher constantly reminded them that every student is responsible for his or her group, and that the purpose of CL activities is to ensure each role for each student in the group is performed. Maintaining students' positive attitudes towards CL is important. Along the process of group work, she first assigned less demanding roles to weaker students, and then progressively assign them with more demanding roles after they were more confident in the tasks that they were doing.

Nevertheless, problems that occur in group work are typically apparent in any teaching method that teachers use. Therefore, in the case of CL, students should be well informed of its principles before it is implemented in the class. For writing class, especially, the students should be provided with more guidance about the basic knowledge of sentence structures, word ordering, and vocabulary. Teachers must always keep an "eagle eye" to members who leave the work for other group members to do. Another way of making sure that the students are being responsible for their task, for example, is by creating an evaluation form where students could evaluate other members' responsibility in their group.

Yet, CL had proven to be one of the best methods in enhancing students' performance in language learning, especially writing, as it promotes cooperation among students and reduced peer competition and isolation, and further promotes academic achievement and positive relationships (Slavin, 2011). CL at the same time leads to higher group and individual achievement, healthier relationship with peers, and greater psychological health and self-esteem (Johnson \& Johnson, 2000; Slavin, 2011). 


\section{CONCLUSION}

The results of this study reveals that the students had performed better in the post-test compared to the pre-test of narrative essay writing after CL method was implemented in the class. They did not only improve in their writing scores, but also showed good progress in the five components of writing. These components are content, organization, vocabulary, grammar and mechanics, and they all are equally important in producing a good piece of writing. The use of CL was found to succeed in encouraging students to work harder on refining their writing skill and this was reflected in the increase of their writing scores in the post-test.

After the students experienced learning using the CL methods in the writing class, in this case by using STAD and Jigsaw, the elements and the effects of these methods had made it possible for the students to improve their writing skill. This improvement is due to the fact that $\mathrm{CL}$ provided them better opportunity to work cooperatively in comfortable situations. Despite some problems faced in its implementations, the teacher managed to overcome them by using some strategies, so that at the end, each member of the group was willing to help each other, especially those with learning weaknesses. Peer acceptance and support was important in helping students to learn better.

Finally, some recommendations for further research are proposed. This study was conducted with a small group consisting of thirty students of the ninth grade in a high school in Kuala Lumpur. So, this study may not be readily generalizable. To upgrade the results, related studies vouch for are those that focus on learners with different level of education, longer time period of data collection, or larger number of students to find out whether there is a significant difference in the students' writing skill before and after the inclusion of CL. Finally, other studies that emphasize on other language skills such as reading, listening, and speaking through other CL methods are also commended to enlighten the potential of CL in developing other language skills.

\section{REFERENCES}

Ahangari, S., \& Samadian, Z. (2014). The effect of Cooperative Learning Activities on Writing Skills of Iranian EFL learners, Linguistics and Literature Studies, 2(4), 121130.

Aronson, E., \& Patnoe, S. (2011). Cooperation in the Classroom: The Jigsaw Method. London: Pinter \& Martin.

Artz, A. F., \& Newman, C. M. (1990). Cooperative learning. Mathematics Teacher, 83, 448-449.

Baloche, L. A. (1998). The Cooperative Classroom: Empowering Learning. Upper Saddle River, NJ: Prentice Hall.

Boals, A. (2012). The Use of Meaning Making in Expressive Writing: When Meaning is Beneficial, Journal of Social and Clinical Psychology, 31(4), 393-409. 
Brereton, J. C. (Ed.). (1995). The Origins of Composition Studies in the American College, 1875-1925. Pittsburgh: University of Pittsburgh Press.

Brown, H. D. (2007). Principles of Language Learning and Teaching. San Francisco. Pearson Education.

Byrne, D. (1993). Teaching Writing Skills. Essex: Longman Group.

Harmer, J. (2004). How to Teach Writing. Harlow: Longman.

Ismail, S., \& Maasum, T. N. R. T. M. (2009). The Effects of Cooperative Learning in Enhancing Writing Performance. Retrieved from http://pkukmweb.ukm.my/ solls09/Proceeding/PDF/Shafini.pdf

Gould, E., DiYanni, R. J., \& Smith, W. (1990). Act of Writing. New York: Schaum Outline Series.

Jacobs, G. M., Power, M. A., \& Inn, L. W. (2002). The Teacher's Sourcebook for Cooperative Learning: Practical Methods, Basic Principles, and Frequently Asked Questions. Thousand Oaks, CA: Corwin Press.

Johnson, R. T., \& Johnson, D. W. (1994). An overview of cooperative learning. In J. S. Thousand, R. A. Villa \& T. A. Nevin (Eds.), Creativity and Collaborative Learning: The Practical Guide to Empowering Students, Teachers, and Families (pp. 31-44). Baltimore: Paul H. Brookes.

Johnson, D. W., \& Johnson, R. T. (1999). Learning Together and Alone, 5th Ed. Boston: Allyn \& Bacon.

Johnson, D. W., \& Johnson, R. T. (2000). Cooperative Learning Methods: A Metaanalysis. Minneapolis: Cooperative Learning Center at the University of Minnesota.

Kagan, S. (1990). The Structural Approach to Cooperative Learning. Educational Leadership, 47, 12-15.

Kagan, S., \& High, J. (2002). Kagan Structures for English Language Learners. San Clemente, CA: Kagan Publishing. Retrieved from https://www.kaganonline.com/free_articles/dr_spencer_kagan/279/Kagan-Structuresfor-English-Language-Learners

Karim, A. A. (2012). Cooperative Learning Strategies in Enhancing Students' Writing Proficiency: The Case of Second Year LMD Students at Mohamed Khidher University (Master's thesis). University of Mohamed Khidher Biskra, Biskra.

Mandal, R. R. (2009). Cooperative Learning Strategies to Enhance Writing Skills, The Modern Journal of Applied Linguistics, 1, 93-102.

Kustati, M., \& Yuhardi. (2014). The Effect of the Peer-Review Technique on Students' Writing Ability, Studies in English Language and Education, 1(2), 71-81.

Mukminatin, N. (1997). The Difference of Students' Writing Achievement across Different Courses Levels (Doctoral dissertation). Malang: State University of Malang. 
Pallant, J. (2001). SPSS Survival Manual: A Step by Step Guide to Data Analysis Using Windows (Version 10). Crows Nest: Allen \& Unwin.

Pusat Perkembangan Kurikulum [Curriculum Development Centre]. (2003). Huraian Sukatan Pelajaran Kurikulum Bersepadu Sekolah Menengah: Bahasa Inggeris [Description of Integrated Curriculum Syllabus for Secondary School: English]. Putrajaya: Kementerian Pelajaran Malaysia.

Raimes, A. (1983). Methods in Teaching Writing. New York: Oxford University Press.

Richards, J. C., \& Rodgers, T. S. (2001). Approaches and Methods in Language Teaching, 2nd Ed. Cambridge: Cambridge University Press.

Richards, J. C., \& Renandya, W. A. (2002). Methodology in Language Teaching. Cambridge: Cambridge University Press.

Slavin, R. E. (1980). Cooperative Learning, Review of Educational Research, 50(2), 315-342.

Slavin, R. E. (1995). Cooperative Learning: Theory, Research and Practice, 2nd Ed. Boston: Allyn and Bacon.

Slavin, R. E. (2011). Instruction based on Cooperative Learning. In R. E. Mayer \& P. A. Alexander (Eds.), Handbook of Research on Learning and Instruction (pp. 344-360). New York: Taylor \& Francis.

Starkey, L. (2004). How to Write Great Essays. New York: Learning Express.

Tierney, R. J., Soter, A., O’Flahavan, J. F., \& McGinley, W. (1989). The Effects of Reading and Writing upon Thinking Critically. Reading Research Quarterly, 24(2), 134-173.

Troyka, L. Q. (2010). Simon \& Schuster Handbook for Writers, 5th Ed. Toronto: Pearson Prentice Hall.

White, H., \& Sabarwal, S. (2014). Quasi-Experimental Design and Methods. Florence: United Nations Children's Fund (UNICEF).

Yusuf, Y. Q., Natsir, Y., \& Hanum, L. (2015). A teacher's Experience in Teaching with Student Teams-Achievement Division (STAD) Technique, International Journal of Instruction, 8(2), 99-112. 